\title{
Effects of Submerged Plants on the Growth of Eutrophic Algae and Nutrient Removal in Constructed Wetlands
}

\section{Zhiqiang Yan ${ }^{*}$, Benru Song1*, Li Zhang1, Mian Liu², Yan Liu², Xiaoye Wu2 ${ }^{2}$ Yunhui Tian', Zhanghe Chen" ${ }^{1 \#}$, Jiangang Zhao ${ }^{3 \#}$}

${ }^{1}$ Key Laboratory of Ecology and Environmental Science of Guangdong Higher Education, College of Life Science, South China Normal University, Guangzhou, China

${ }^{2}$ Lingnan Landscape Co., Ltd., Dongguan, China

${ }^{3}$ Key Laboratory of Eutrophication and Red Tide Prevention of Guangdong Higher Education Institute, Jinan University, Guangzhou, China

Email: "chenzhh@scnu.edu.cn, "zhjg@jnu.edu.cn

How to cite this paper: Yan, Z.Q., Song, B.R., Zhang, L., Liu, M., Liu, Y., Wu, X.Y., Tian, Y.H., Chen, Z.H. and Zhao, J.G. (2016) Effects of Submerged Plants on the Growth of Eutrophic Algae and Nutrient Removal in Constructed Wetlands. Open Access Library Journal, 3: e3056. http://dx.doi.org/10.4236/oalib.1103056

Received: September 12, 2016

Accepted: October 6, 2016

Published: October 11, 2016

Copyright $\odot 2016$ by authors and Open Access Library Inc.

This work is licensed under the Creative Commons Attribution International License (CC BY 4.0).

http://creativecommons.org/licenses/by/4.0/ cc) (i) Open Access

\section{Abstract}

We studied the nutrition removal, taxa and density of phytoplankton, concentration of chlorophyll-a (chl-a) of the monoculture constructed wetlands (CWs) planted with submerged macrophytes Hydrilla verticillata, Elodea nuttallii, Myriophyllum spicatum and Vallisneria natans to probe the nutrient and alga removal effects of the CWs. The CWs had significant differences $(\mathrm{P}<0.01)$ in removing different nutrients, with $E$. nuttallii wetland having the highest removal rate of total phosphorus (TP), $H$. verticillata wetland having the highest removal rate of ammonia nitrogen $\left(\mathrm{NH}_{4}-\mathrm{N}\right)$ and $M$. spicatum wetland having the highest removal rate of chemical oxygen demand $\left(\mathrm{COD}_{\mathrm{Cr}}\right)$. Removal rates of all the nutrients except $\mathrm{COD}_{\mathrm{Cr}}$ changed obviously with seasons. The concentrations of chl-a and the density of phytoplankton in the CWs also varied with seasons, with the values being significantly lower in winter than in summer $(\mathrm{P}<0.01)$. E. nuttallii wetland had a significantly lower chl-a concentration than the other wetlands $(\mathrm{P}<0.01)$. Macrophyte biomass was significantly different among these wetlands $(\mathrm{P}<0.01)$. E. nuttallii wetland had higher inhibition ability on algae than the other three wetlands in summer $(\mathrm{P}<0.05)$, and $E$. nuttallii and $M$. spicatum wetlands than $H$. verticillata and $V$. natans wetlands in winter $(\mathrm{P}<0.05)$.

\section{Subject Areas}

Environmental Sciences 


\section{Keywords}

Constructed Wetlands, Submerged Plant, Biomass, Nutrient Removal, Alga Density

\section{Introduction}

Eutrophication and harmful alga bloom are the world's widespread environmental problems [1]. In recent decades, under global change and human disturbance the nitrogen and phosphorus nutrient pollution load is increasing, and algal blooms become more likely to occur [2].

In a variety of measures for eutrophic water restoration, the methods of using aquatic plants, with its good purification effect, unique economic efficiency, low energy consumption, simple and feasible, and ecological benefits, are increasingly attracting people's attention [3]. Constructed wetlands (CWs) have numerous advantages, such as low construction and running costs, good removal efficiency, low energy consumption and good landscape effects, so the CWs with aquatic plants have become one of the feasible ways to process various kinds of eutrophic water, living and industrial wastewater [4].

Wetland plants are an important part of the CWs, including emerging plants, floating plants and submerged plants, which play an important role in purifying wastewater [5]. At present emerging plants are the most widely researched and applied plants in CWs; floating plants are widely used to remove nitrogen and phosphorus and improve the efficiency of stabilization ponds, but research and application of CWs consisting submerged plants are still scarce. A large number of experiments showed that restoration of aquatic plants and the construction of the grass type lake ecosystem are widely considered to be effective means for eutrophic water restoration [6], and the restoration of submerged plants in eutrophic waters has become one of the key contents of water ecology research [7].

Submerged plants are the main primary producers in aquatic ecosystems, and play an important role in regulating the ecological balance of water ecosystem [6]. Submerged plants absorb nitrogen and phosphorus in water and sediment, and inhibit the growth of algae through compete growth resources [8] [9]. Tanaka et al. found that the CWs vegetated with submerged plants had quite high removal rates of $\mathrm{COD}_{\mathrm{Cr}}[9], \mathrm{NH}_{4}-\mathrm{H}$, total suspended solids and TP. At the same time many submerged plants can produce allelochemicals to kill or inhibit algae in the water [10] [11]. Submerged plants can also supply a large surface area for macrozooplankton adhesion, feeding a large number of phytoplankton, which thus can control alga population indirectly [12]. Submerged plants can realize the purification of water through adsorption of biological and nonbiological suspended materials in water, improve water transparency and increase the dissolved oxygen of water [13] [14]. Science the 80s of the twentieth century, the reconstruction of submerged plant communities and the restoration of aquatic ecosystem functions through artificial means have become the important contents in the projects 
of sewage treatments. Studies on the growth conditions of submerged plants have achieved some results [15] [16]. However, in the field practices submerged plants are often difficult to survive and to form stable communities through plantation. Growth, survival and reproduction of submerged plants are affected by multiple factors, such as light intensity, nutrients, sediment, suspended solids and water temperature [17] [18]. In addition, the alga bloom in eutrophic water will block the light and compete nutrients with submerged plants. At present, field experiments on submerged plants are still quite lack, and the document on submerged macrophyte experimental results still cannot effectively guide the field practice. The object of the present study is to probe the nutrient and alga removal effects of the CWs vegetated with different submerged macrophytes in field conditions, in order to provide the theoretical basis and practical reference for the application of submerged plants in restoration of eutrophic water.

\section{Materials and Methods}

\subsection{Wetland Construction}

H. verticillata, E. nuttallii, $M$. spicatum and $V$. natans used in this experiment was bought from Huadiwan bird-and-fish market in Fangcun of Guangzhou. The plants with similar growth status were cleaned with tap water and distilled water before experiment.

The experiment was conducted in the seedling base of Lingnan Landscape Co., Ltd. in Huizhou, Guangdong Province. The experiment used cylindrical plastic barrels (upper diameter 50 , lower diameter 45 , and height $55, \mathrm{~cm}$ ) to build small CWs filled with $15 \mathrm{~cm}$ thick sand cleaned with distilled water as the matrix. In May 2013, each wetland was planted with equal biomass of $H$. verticillata, $E$. nuttallii, $M$. spicatum and $V$. natans. Each specific wetland had 12 replications. After planted each wetland poured into $60 \mathrm{~L}$ water, 2 weeks later each wetland poured into $30 \mathrm{~L}$ water and $30 \mathrm{~L}$ artificial wastewater, and then poured into $60 \mathrm{~L}$ artificial wastewater per month. The artificial wastewater was prepared after $\mathrm{He}$ et al. [19], with the concentration $\left(\mathrm{mg} \cdot \mathrm{L}^{-1}\right)$ of $\mathrm{COD}_{\mathrm{Cr}}$, total nitrogen (TN) and TP being 100, 20 and 2.5 respectively. The experiment end in December 2013.

\subsection{Sampling and Measurement}

Water quality measurement was conducted monthly. The nutrient concentration was tested after a 2-d-retention. Effluent samples were taken from the upper, lower, and middle parts of the wetlands, and then mixed and packed in $200 \mathrm{~mL}$ ethylene plastic bottles for immediate laboratory analysis.

The chl-a concentration was tested spectrophotometrically after a 10-d-retention from about $300 \mathrm{~mL}$ of water samples which were filtered through glass-fiber filters and extracted with $90 \%$ acetone solution for more than $20 \mathrm{~h}$.

The taxa and the density of the phytoplankton were measured one month after irrigation in July and December. Water samples of $1000 \mathrm{~mL}$ were obtained using a cylindrical sampler. The water samples were preserved with Lugol's iodine and sedimented 
for more than $48 \mathrm{~h}$. The supernatant was removed and the sediment of about $30 \mathrm{~mL}$ was collected. The alga density was counted from $0.1 \mathrm{~mL}$ of the sediment through a 0.1 $\mathrm{mL}$ counting chamber using a microscope at $40 \times 10$ magnification. Alga taxa was identified to species or varieties according to $\mathrm{Hu}$ and Wei (2006) [20], and alga biomass was estimated according to the closest geometric shape of each taxa.

Nutrient concentration was measured according to the methods of The Environment Bureau of the State [21]. TP was measured using molybdenum-antimony anti-spectrophotometric method, $\mathrm{NH}_{4}-\mathrm{N}$ was measured using reagent colorimetric method, and $\mathrm{COD}_{\mathrm{Cr}}$ was measured using potassium dichromate method.

Half of the specific CWs were harvested randomly in August, and fresh weight after washing and dry weight after drying at $80^{\circ} \mathrm{C}$ for $24 \mathrm{~h}$ were measured. All the other wetlands were harvested at the end of the experiment and the fresh and the dry weights were measured using the same methods.

Competition indices between the submerged plants and algae were assessed based on the relative yield (RY) [22], relative competitive intensity (RCI) [23], and relative crowding coefficient (RCC) [24]. The relevant formulae are as follows:

$$
\begin{aligned}
& R Y_{a}=Y_{a b} /\left(P_{a} / Y_{a}\right), \\
& R C l_{a}^{*}=\left(P_{a} Y_{a}-Y_{a b}\right) / P_{a} Y_{a}=1-R Y_{a}, \\
& R C C_{a}^{*}=P_{b} Y_{a b} / P_{a}\left(Y_{a}-Y_{a b}\right) .
\end{aligned}
$$

where $a$ is submerged plant, $b$ is alga, $Y$ is biomass, $P_{a}, P_{b}$ is the proportion of species $a$ and $b$ respectively, $Y_{a b}$ shows the biomass of $a$ in the presence of $b, Y_{a}$ shows the biomass of $a$ in monoculture, and ${ }^{*}$ shows that $a$ in the formulae can be displaced by $b$.

Statistical analysis was conducted using SPSS18.0 and further analysis of the significant differences between intra-species and interspecies was processed using a twofactor ANOVA.

\section{Results and Analysis}

\subsection{Nutrient Removal Efficiency}

There was significant difference among the four CWs on TP removal rates $(\mathrm{P}<0.01$, Figure 1(a)). Annual average removal rate of E. nuttallii wetland was the highest and significant higher than that of $M$. spicatum wetland $(\mathrm{P}<0.05)$. Removal rate of $E$. nuttallii wetland was significantly higher than those of the other wetlands in July, August and September $(\mathrm{P}<0.05)$. TP removal rates of the CWs varied significantly with seasons with higher removal rates in July to September (Figure 1(a)). TP removal rate of $M$. spicatum wetland was highest in July, and those of the other wetlands were highest in September.

$\mathrm{NH}_{4}-\mathrm{H}$ removal rates were significant different among the specific CWs $(\mathrm{P}<0.01$, Figure 1(b)). Annual average removal rate of $H$. verticillata wetland was the highest and significantly higher than that of E. nuttallii wetland ( $\mathrm{P}<0.05)$. Removal rate of $H$. verticillata wetland was significantly higher than those of the other wetlands in July and September $(\mathrm{P}<0.05) . \mathrm{NH}_{4}-\mathrm{H}$ removal rates of the $\mathrm{CWs}$ varied significantly with 

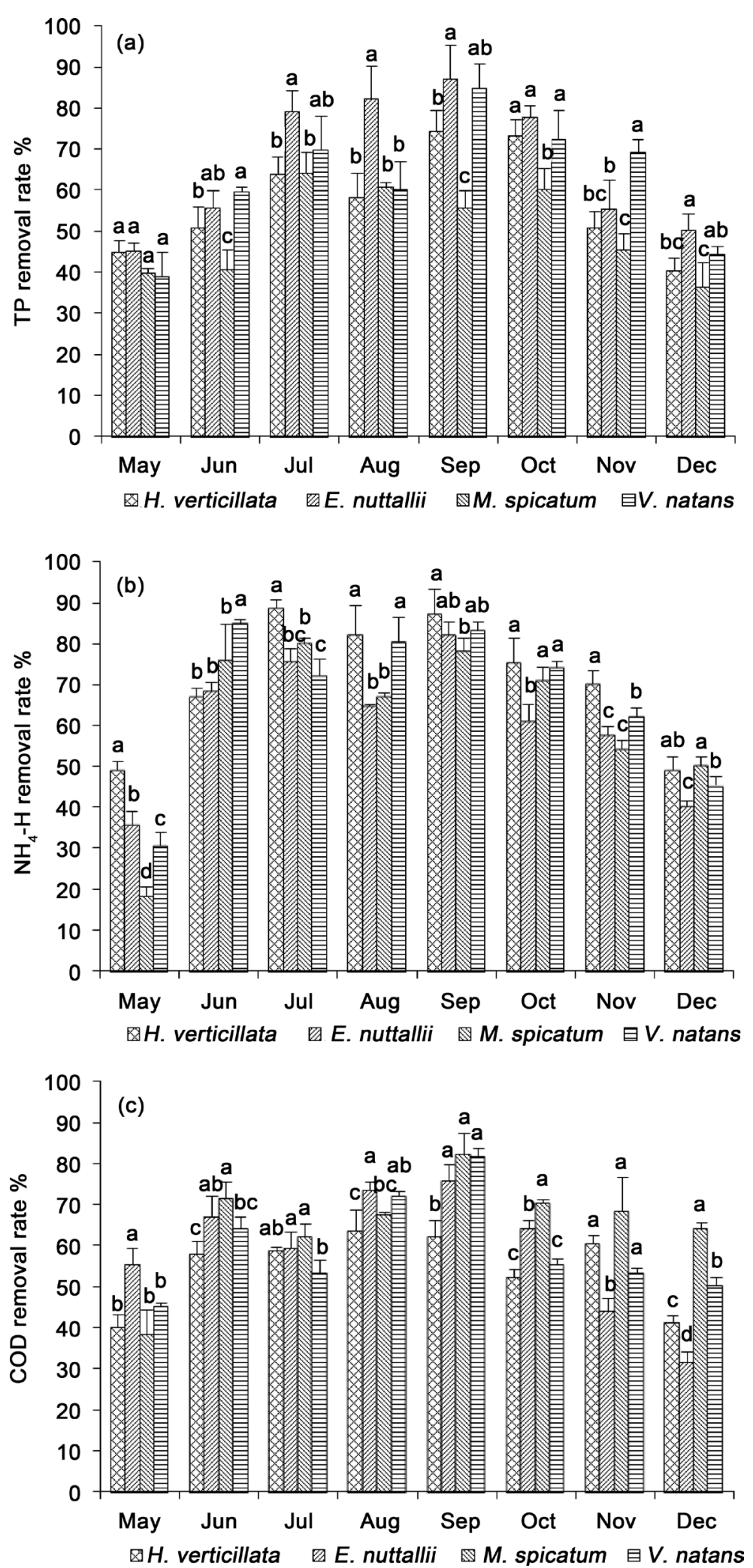

Figure 1. Nutrient removal rates of the monoculture CWs vegetated with submerged plants $H$. verticillata, E. nuttallii, M. spicatum and V. natans. Different letters indicate significant differences among different CWs $(\mathrm{P}<0.05)$. 
seasons with higher rates in summer months, and with different CWs having higher rates in different months (Figure $1(\mathrm{~b})$ ).

There were significant differences in $\mathrm{COD}_{\mathrm{Cr}}$ removal rates among the CWS $(\mathrm{P}<0.01$, Figure $1(\mathrm{c})$ ). M. spicatum wetland had a significantly higher removal rate than the other three wetlands throughout the year $(\mathrm{P}<0.05)$. $\mathrm{COD}_{\mathrm{Cr}}$ removal rates varied significantly with seasons. $H$. verticillata wetland had a higher removal rate in August, and the other wetlands had higher rates in September.

\subsection{Concentration of chl-a}

There were significant differences in chl-a concentration among the CWs $(\mathrm{P}<0.01)$ (Figure 2). Annual average chl-a concentration in E. nuttallii wetland was significantly lower than the other three wetlands $(\mathrm{P}<0.01)$, and $V$. natans wetland had the highest chl-a concentration. Chl-a concentration of the CWs presented a marked seasonal variation, with higher values in summer and lower values in winter (Figure 2).

\subsection{Macrophyte Biomass}

Macrophyte biomass varied significantly among the CWs $(\mathrm{P}<0.05)$ (Figure 3). E. nuttallii wetland had the largest biomass, and $M$. spicatum wetland had the smallest value.

Macrophyte biomass varied significantly with seasons $(\mathrm{P}<0.01)$, with significantly higher biomass in summer than winter $(\mathrm{P}<0.05)$ for all the wetlands except $M$. spicatum wetland (Figure 3 ). In summer, the biomass represented a greater difference among the CWs than in winter.

\subsection{Phytoplankton Taxa and Density}

Species of phytoplankton in all wetland were significantly more in summer than in winter (Table 1). There were at least five dominant species in all wetland in summer,

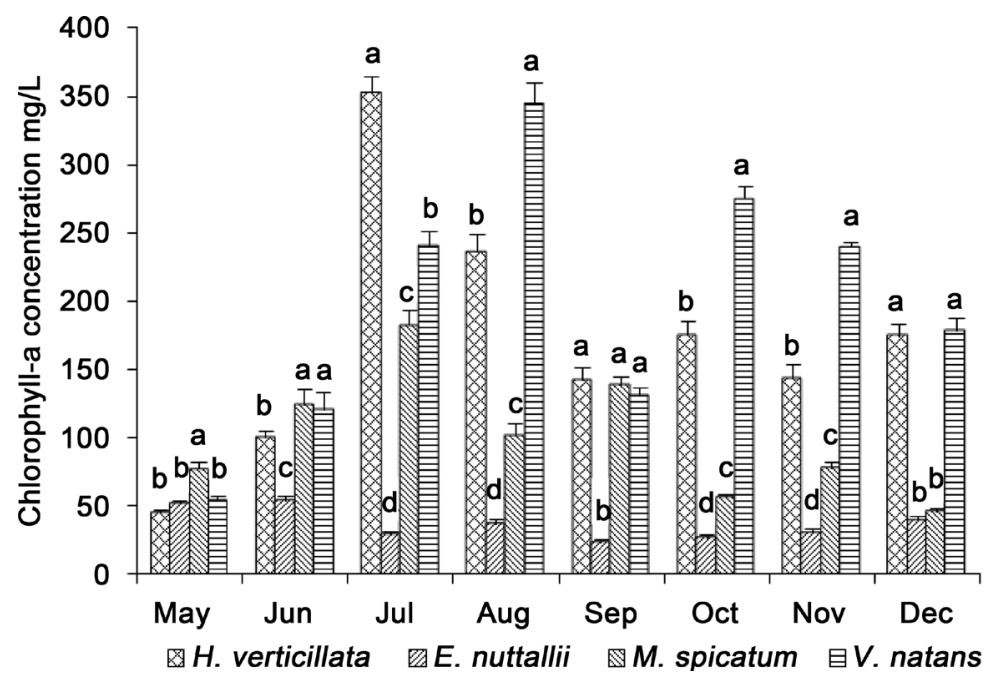

Figure 2. Chlorophyll-a concentration 10 days after the sewage input in the monoculture CWs vegetated with submerged plants $H$. verticillata, E. nuttallii, M. spicatum and V. natans. Different letters indicate significant differences among different CWs $(\mathrm{P}<0.05)$. 


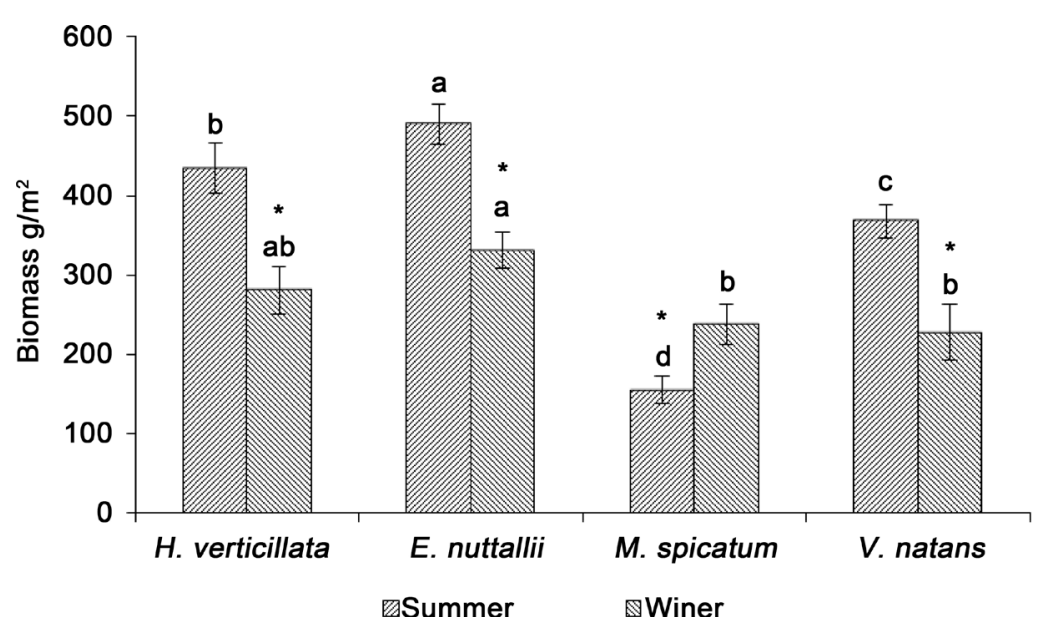

Figure 3. Macrophyte biomass in the monoculture CWs vegetated with submerged plants $H$. verticillata, E. nuttallii, M. spicatum and V. natans. ${ }^{\star}$ Indicates significant differences between seasons in the same CW $(\mathrm{P}<0.05)$, and different letters indicate significant differences among different CWs in the same season $(\mathrm{P}<0.05)$.

Table 1. Taxa and density of the phytoplankton in the four monoculture CWs vegetated with submerged plants $H$. verticillata, $E$. nuttallii, M. spicatum and $V$. natans.

\begin{tabular}{|c|c|c|c|c|c|c|c|c|}
\hline \multirow{2}{*}{ Phytoplankton } & \multicolumn{2}{|c|}{ H. verticillata CWs } & \multicolumn{2}{|c|}{ E. nuttallii CWs } & \multicolumn{2}{|c|}{ M. spicatum $\mathrm{CWs}$} & \multicolumn{2}{|c|}{$V$. natans $\mathrm{CWs}$} \\
\hline & July & December & July & December & July & December & July & December \\
\hline Scenedesmus quadricauda & + & + & + & + & + & + & + & - \\
\hline Chlorella vulgaris & + & + & + & - & + & + & - & + \\
\hline Cryptomonas ovata & + & + & + & - & - & + & + & - \\
\hline Mallomonas caudata & + & - & + & - & - & - & + & - \\
\hline Botryocladia leptopoda & + & + & - & - & - & - & - & - \\
\hline Chroomonas acuta & + & - & - & - & + & - & - & - \\
\hline Cyclotella meneghiniana & - & - & - & - & + & - & + & - \\
\hline Merismopedia glauca & - & - & - & - & - & - & + & + \\
\hline Cryptomonas erosa & - & - & + & - & - & - & - & - \\
\hline $\begin{array}{c}\text { Chlamydomonas } \\
\text { microsphaera }\end{array}$ & - & - & - & + & - & - & - & - \\
\hline Trachelomonas viridis & - & - & - & - & + & - & - & - \\
\hline
\end{tabular}

Note: "+" alga cells more than $5 \times 10^{8} \mathrm{~L}^{-1}$; “-" alga cells less than $5 \times 10^{8} \mathrm{~L}^{-1}$.

but were all less than four in winter. Scenedesmus quadricauda was always the main alga both in summer and in winter, and Chlorella vulgaris and Cryptomonas ovata also had larger dominance.

\subsection{Competitive Indices of Plants and Algae}

The relative yield (RY) of $E$. nuttallii wetland was more than 1 (Table 2). This indicated that the intraspecific competition of the plant was more serious than the competition 
between the plant and the phytoplankton. The RYs of $H$. verticillata and $V$. natans wetlands were less than 1 , indicating that the influence of phytoplankton on these plants was more serious than the intraspecific competition of these plants. The RYs were not significantly different between winter and summer for all the wetlands except $M$. spicatum wetland.

The relative competitive intensity (RCI) of E. nuttallii wetland was measured a negative value, indicating that the competition between $E$. nuttallii and phytoplankton was small. RCIs of $H$. verticillata and $V$. natans wetlands displayed positive values, indicating that the competition between plants and phytoplankton was serious. M. spicatum wetland was slightly influenced by competition in winter, and more seriously in summer. The competition between the plants and phytoplankton in other wetlands was not significantly different between summer and winter.

E. nuttallii wetland had the smallest relative crowding coefficient (RCC) (Table 2), indicating that this plant had stronger competition ability over the phytoplankton than other plants. M. spicatum wetland also had smaller RCC value. All the four specific CWs had RCC values close to 0 in summer, indicated that all the submerged plants had a strong competitive ability over phytoplankton in summer.

On the whole, the competitive intensity of $E$. nuttallii over phytoplankton was stronger than the other three plants. $H$. verticillata also had a stronger competitive ability over the algae, especially in winter.

\section{Discussion}

Nutrient removal rates were significantly different among the CWs $(\mathrm{P}<0.01)$, and the four submerged plants had respective advantages in removing different nutrients. $E$. nuttallii wetland has the highest removal rate for TP; $H$. verticillata wetland has the highest removal rate for $\mathrm{NH}_{4}-\mathrm{N}$ and $M$. spicatum wetland has the highest removal efficiency for $\mathrm{COD}_{\mathrm{Cr}}$. This suggests that it should be on a comprehensive basis to evaluate the nutrient removal efficiency of submerged plants. This also suggests that mixed CWs are likely to have a better comprehensive nutrient removal effect. However, little has been known about the interactions of mixed submerged plants in the CWs in growth and nutrient removal.

Removal rates of the measured nutrients in the present study except $\mathrm{COD}_{\mathrm{Cr}}$ varied significantly with seasons. This might correlate with the seasonal variation of the

Table 2. Competition indices between the four submerged plants and algae in the monoculture CWs.

\begin{tabular}{|c|c|c|c|c|c|c|}
\hline Wetlands species & \multicolumn{2}{|c|}{ Relative yield (RY) } & \multicolumn{2}{|c|}{ Relative competitive intensity (RCI) } & \multicolumn{2}{|c|}{ Relative crowding coefficient (RCC) } \\
\hline H. verticillata $\mathrm{CWs}$ & $0.6667 \pm 0.0051$ & $0.8623 \pm 0.1012$ & $0.3333 \pm 0.0732$ & $0.1383 \pm 0.0125$ & $0.0839 \pm 0.1120$ & $0.1700 \pm 0.9634$ \\
\hline E. nuttallii CWs & $1.1152 \pm 0.0342$ & $1.0664 \pm 0.0367$ & $-0.1152 \pm 0.024$ & $-0.0663 \pm 0.0054$ & $-0.0394 \pm 0.1327$ & $-0.0950 \pm 0.0247$ \\
\hline M. spicatum CWs & $0.6708 \pm 0.0965$ & $1.0109 \pm 0.0462$ & $0.3292 \pm 0.0421$ & $-0.1090 \pm 0.0325$ & $0.0509 \pm 0.0331$ & $-0.0900 \pm 0.3416$ \\
\hline
\end{tabular}


growth of the submerged plants and the microorganisms. The growth of the submerged plants was more vigorously in summer, and the microorganisms had higher metabolism rate in summer. Microorganism and aquatic plants were two important factors in the nutrient removal of CWs [25]. High water temperature in summer also makes the algae grow more quickly, which might be also responsible for the higher removal rates in summer months.

In the present study, E. nuttallii wetland had the lowest chl-a concentration. This might correlate with its vigorous growth and the largest biomass. However, M. spicatum, which had the smallest biomass, had also lower chl-a density. This suggests that there might be other mechanisms for the alga inhibition in the submerged plant CWs other than the direct competition for light and nutrients between the submerged macorphytes and the algae, for example allelopathy.

The phytoplankton species in the present experiment were mainly those of Scenedesmus, Chlorella and Cryptomons. All these alga were indicator species of eutrophication, although different eutrophic waters have different alga indicator species [26]. Even with the vegetation of submerged plants, water quality in our experiment CWs was basic in eutrophic state. Study of Kocum \& Sutcu [27] also confirmed this rule, and they also found that proportion of Scenedesmus was higher in stations with severer pollution. Barone \& Naselli-Flores [28] found that in a small eutrophic temporary pond, without grazing pressure in spring, the Cryptomonads bloomed in summer.

As can be seen from the relative yield, relative competitive intensity and relative crowding coefficient, the intraspecific competition in E. nuttallii wetland was stronger than the interspecific competition both in summer and winter. This means that the inhibition ability of $E$. nuttallii on alga growth was efficient all over the year. The intraspecific competition was stronger than interspecific competition in $M$. spicatum wetland in winter. This might correlate with the better growth of this species in winter, and might be due to the lower growth and reproduction of the algae in winter. We conjectured that the high inhibition ability of E. nuttallii might be due to its strong adaptability and high biomass, and that of $M$. spicatum might be due to its allelopathy.

\section{Funding}

Supported by the Baiyun District Water Supplies Bureau Ecological Restoration Project for Shima Wetland Park Eutrophication Lake, the Fundamental Research Funds for the Central Universities (11613301), the Special Project on the Integration of Industry, Education and Research in Guangdong Province (2012B09090001) and the project of the Urban Management Bureau of Shenzhen (201510).

\section{References}

[1] Smith, V.H. and Schindler, D.W. (2009) Eutrophication Science: Where Do We Go from Here? Trends in Ecology \& Evolution, 24, 201-207. http://dx.doi.org/10.1016/j.tree.2008.11.009

[2] Howarth, R.W. (2008) Coastal Nitrogen Pollution: A Review of Sources and Trends Globally and Regionally. Harmful Algae, 8, 14-20. http://dx.doi.org/10.1016/j.hal.2008.08.015 
[3] Melzer, A. (1999) Aquatic Macrophytes as Tools for Lake Management. Hydrobiologia, 395, 181-190. http://dx.doi.org/10.1023/A:1017001703033

[4] Weber, A., Lautenbach, S. and Wolter, C. (2012) Improvement of Aquatic Vegetation in Urban Waterways Using Protected Artificial Shallows. Ecological Engineering, 42, 160-167. http://dx.doi.org/10.1016/j.ecoleng.2012.01.007

[5] Kivaisi, A.K. (2001) The Potential for Constructed Wetlands for Wastewater Treatment and Reuse in Developing Countries: A Review. Ecological Engineering, 16, 545-560. http://dx.doi.org/10.1016/S0925-8574(00)00113-0

[6] Weisner, S.E., Strand, J.A. and Sandsten, H. (1997) Mechanisms Regulating Abundance of Submerged Vegetation in Shallow Eutrophic Lakes. Oecologia, 109, 592-599.

http://dx.doi.org/10.1007/s004420050121

[7] Lauridsen, T.L., Jensen, J.P., Jeppesen, E. and Søndergaard, M. (2003) Response of Submerged Macrophytes in Danish Lakes to Nutrient Loading Reductions and Biomanipulation. Hydrobiologia, 506, 641-649. http://dx.doi.org/10.1023/B:HYDR.0000008633.17385.70

[8] Horppila, J. and Nurminen, L. (2003) Effects of Submerged Macrophytes on Sediment Resuspension and Internal Phosphorus Loading in Lake Hiidenvesi (Southern Finland). Water Research, 37, 4468-4474. http://dx.doi.org/10.1016/S0043-1354(03)00405-6

[9] Tanaka, N., Jinadasa, K.B.S.N., Werellagama, D.R.I.B., Mowjood, M.I.M. and Ng, W.J. (2006) Constructed Tropical Wetlands with Integrated Submergent-Emergent Plants for Sustainable Water Quality Management. Journal of Environmental Science and Health (Part A), 41, 2221-2236. http://dx.doi.org/10.1080/10934520600867581

[10] Ervin, G.N. and Wetzel, R.G. (2003) An Ecological Perspective of Allelochemical Interference in Land-Water Interface Communities. Plant and Soil, 256, 13-28. http://dx.doi.org/10.1023/A:1026253128812

[11] Zhao, J.G., He, F.F., Chen, Z.H., Li, H.J., Hu, J.M. and Lin, F.P. (2012) Effect of Culture and Extract Solutions of Macrophytes on the Growth of Three Common Algae. Journal of Freshwater Ecology, 27, 367-379. http://dx.doi.org/10.1080/02705060.2012.661936

[12] Špoljar, M., Dražina, T., Šargač, J., Borojević, K.K. and Žutinić, P. (2012) Submerged Macrophytes as a Habitat for Zooplankton Development in Two Reservoirs of a Flow-Through System (Papuk Nature Park, Croatia). Annales de Limnologie-International Journal of Limnology. EDP Sciences, 48, 161-175.

[13] Horppila, J. and Nurminen, L. (2005) Effects of Different Macrophyte Growth Forms on Sediment and P Resuspension in a Shallow Lake. Hydrobiologia, 545, 167-175. http://dx.doi.org/10.1007/s10750-005-2677-9

[14] Dudley, B., Gunn, I.D.M., Carvalho, L., Proctor, I., O’Hare, M.T., Murphy, K.J. and Milligan, A. (2012) Changes in Aquatic Macrophyte Communities in Loch Leven: Evidence of Recovery from Eutrophication? Hydrobiologia, 681, 49-57. http://dx.doi.org/10.1007/s10750-011-0924-9

[15] Comín, F.A., Menéndez, M. and Lucena, J.R. (1990) Proposals for Macrophyte Restoration in Eutrophic Coastal Lagoons. In: Biomanipulation Tool for Water Management, Springer Netherlands, 427-436. http://dx.doi.org/10.1007/978-94-017-0924-8_37

[16] Takamura, N., Kadono, Y., Fukushima, M., Nakagawa, M. and Kim, B.H. (2003) Effects of Aquatic Macrophytes on Water Quality and Phytoplankton Communities in Shallow Lakes. Ecological Research, 18, 381-395. http://dx.doi.org/10.1046/j.1440-1703.2003.00563.x

[17] Havens, K.E., Sharfstein, B., Brady, M.A., East, T.L., Harwell, M.C., Maki, R.P. and Rodusky, A.J. (2004) Recovery of Submerged Plants from High Water Stress in a Large Subtropical Lake in Florida, USA. Aquatic Botany, 78, 67-82. 
http://dx.doi.org/10.1016/j.aquabot.2003.09.005

[18] Irfanullah, H.M. and Moss, B. (2004) Factors Influencing the Return of Submerged Plants to a Clear-Water, Shallow Temperate Lake. Aquatic Botany, 80, 177-191. http://dx.doi.org/10.1016/j.aquabot.2004.07.010

[19] He, R., Zhang, Q. and Zhang, J. (2004) Treating Domestic Sewage by the Free-Water Surface Constructed Wetlands. Ecology and Environment, 13, 180-181.

[20] Hu, H.J. and Wei, J.Y.X. (2006) Chinese Freshwater Algae: System Classification and Ecology. Science Press, Beijing.

[21] The Environment Bureau of the State (2002) A Method of Water and Waste Water Monitoring and Analysis. 4th Edition, China Environmental Science Press, Beijing, 123-207.

[22] Fowler, N. (1982) Competition and Coexistence in a North Carolina Grassland: III. Mixtures of Component Species. Journal of Applied Ecology, 70, 77-92. http://dx.doi.org/10.2307/2259865

[23] Grace, J.B. (1995) On the Measurement of Plant Competition Intensity. Ecology, 76, 305308. http://dx.doi.org/10.2307/1940651

[24] Firbank, L.G. and Watkinson, A.R. (1985) On the Analysis of Competition within TwoSpecies Mixtures of Plants. Journal of Applied Ecology, 22, 503-517. http://dx.doi.org/10.2307/2403181

[25] Liang, W., Wu, Z.B., Cheng, S.P., Zhou, Q.H. and Hu, H.Y. (2003) Roles of Substrate Microorganisms and Urease Activities in Wastewater Purification in a Constructed Wetland System. Ecological Engineering, 21, 191-195. http://dx.doi.org/10.1016/j.ecoleng.2003.11.002

[26] Kuang, Q., Bi, Y., Xia, Y. and Hu, Z. (2004) Phytoplankton Community and Algal Growth Potential in Taipinghu Reservoir, Anhui Province, China. Lakes \& Reservoirs: Research \& Management, 9, 119-124. http://dx.doi.org/10.1111/j.1440-1770.2004.00238.x

[27] Kocum, E. and Sutcu, A. (2013) Analysis of Variations in Phytoplankton Community Size-Structure along a Coastal Trophic Gradient. Journal of Coastal Research, 30, 777-784.

[28] Barone, R. and Naselli-Flores, L. (2003) Distribution and Seasonal Dynamics of Cryptomonads in Sicilian Water Bodies. Hydrobiologia, 502, 325-329.

http://dx.doi.org/10.1023/B:HYDR.0000004290.22289.c2

Submit or recommend next manuscript to OALib Journal and we will provide best service for you:

- Publication frequency: Monthly

- 9 subject areas of science, technology and medicine

- Fair and rigorous peer-review system

- Fast publication process

- Article promotion in various social networking sites (LinkedIn, Facebook, Twitter, etc.)

- Maximum dissemination of your research work

Submit Your Paper Online: Click Here to Submit

Or Contact service@oalib.com 